\title{
The Challenges of Environmental Law Enforcement to Implement SDGs in Indonesia
}

\author{
Agus Salim* and Liberthin Palullungan
}

\author{
Faculty of Law, Universitas Kristen Indonesia Paulus, Makassar, Indonesia
}

\begin{abstract}
The 1945 Constitution of the Republic of Indonesia mandates that a good and healthy environment is a human right and constitutional right for every Indonesian citizen. Therefore, the state, government, and all stakeholders must protect and manage the environment to implement sustainable development. The Indonesian environment can remain a source and support for the Indonesian people; this is in line with implementing the SDGs. The study aims to analyze environmental law enforcement efforts in Indonesia towards SDGs implementation. The research method used a normative approach, with statutory and a conceptual process. The data collect the use of secondary data with literature and statue approach. The study results showed that environmental law enforcement in Indonesia (Number 32/2009) concerning Environmental Protection and Management is preventive and repressive. Three legal instruments in environmental law enforcement are recognized administrative, civil, and criminal law. Environmental law enforcement and the implementation of SDGs in Indonesia are connected. The government implements preventive and repressive law enforcement as regulated in Law by granting expansive powers to local governments to provide protection and environmental management in their respective regions so that the environment remains sustainable. The regulation is in line with the Goals of $6,7,12,13,14$, and 15 of the SDGs directly related to environmental sustainability.
\end{abstract}

Keywords: Environmental Law, Sustainable Development Goals, SDGs.

\section{INTRODUCTION}

A beautiful and green living environment is a gift given by God to humankind to be appropriately preserved so that environmental sustainability can last and be enjoyed from generation to generation. The environment is also a significant aspect of efforts to maintain human life. Without a healthy living environment, humans will undoubtedly find it difficult to survive. Problems in the ground, such as destruction, illegal logging, uncontrolled land clearing, and forest fires, are factors that support natural disasters in an area, experienced by almost every country in the world. The extent of environmental damage and uncontrolled industrial operations make countries experience many disasters. This is the international community's concern so that environmental aspects are included in global action to realize the Sustainable Development Goals (SDGs). The state makes several regulations to protect and preserve the environment so that damage can be controlled; law enforcement is also carried out strictly to protect the increasingly severe environmental degradation (White 2014). Therefore, it is not surprising that ecological dispute resolution is carried out through a litigation process (Hooper et al. 2005). In the context of regulation in Indonesia, the 1945 Constitution of the Republic of Indonesia mandates that a good and healthy environment is a human right and constitutional

*Address correspondence to this author at the Faculty of Law, Universitas Kristen Indonesia Paulus, Makassar, Postal Address: Perintis Kemerdekaan Km. 13 Daya, Kapasa, Makassar, Kota Makassar, Sulawesi Selatan 90245, Indonesia; Tel: +6281241038445; E-mail: agus_salim@ukipaulus.ac.id right for every Indonesian citizen. Therefore, the state, government, and all stakeholders must protect and manage the environment to implement sustainable development. The Indonesian environment can continue to be a source and life support for the Indonesian people and other living creatures. This is a philosophical aspect of the formation of Law of the Republic of Indonesia Number 32/2009 concerning Environmental Protection and Management (Hidjaz 2019; Nazir et al. 2020; Murdifin et al. 2019).

Environmental damage is carried out in an organized manner; therefore, it requires comprehensive efforts to tackle environmental damage (Bhuian and Sharma 2017). The use of natural resources must be in harmony and balance with the environment's functions. Consequently, development policies, plans, and programs must be imbued with the obligation to conserve the environment and realize sustainable development goals. Law of the Republic of Indonesia, Number 32/2009 concerning Environmental Protection and Management, requires the Government and regional governments to make strategic environmental studies to ensure that sustainable development principles have become the basis and are integrated into the development of area policies and plans program. In other words, the results of strategic environmental studies must be used as the basis for development policies, procedures, or programs in an area (Suriyanti et al., 2020). If the strategic environmental assessment results state that the carrying has been exceeded, the development policies, plans, or programs; must be improved as per the strategic environmental study's recommendations. 
These two indicators, namely the carrying capacity of the environment, are determining factors in keeping the environment sustainable.

Science and technology have improved the quality of life and changed people's lifestyles. The use of chemical-based products has increased the production of hazardous and toxic waste. A lot of rubbish is not managed correctly to pollute the environment and violate state regulations regarding the environment (Albrizio, Kozluk, and Zipperer 2017); (Saputro and Basuki 2019). To realize SDGs requires developing a safe disposal system with minimal risk to the ground, health, and survival of humans and other living things. In addition to producing products that are beneficial to society, industrialization also has an impact, among others, on the production of hazardous and toxic waste, which, if disposed of into environmental media, can threaten the environment, health, and the survival of humans and other living creatures. By realizing this, hazardous and toxic materials and their wastes need to be appropriately protected and managed. The territory of the Unitary State of the Republic of Indonesia must be free from dumping hazardous and toxic waste from outside Indonesia's region; hence a more systematic understanding of the stakeholders is needed to prevent and overcome environmental crimes (Obidzinski et al. 2012). Hazardous waste is a frightening specter for society. The current development and rapidly increasing industrialization are accompanied by the failure to define \& understand the precise definition of dangerous waste, which, as a result, allows the misrepresentation of waste delivery easily. Realizing the potential negative impacts that may arise as a consequence of development, efforts to control the effects are continuously developed at an early stage. Environmental impact analysis is one of the preemptive tools for environmental management that continues to be strengthened through increased accountability in the implementation, by requiring the environmental impact analysis by requiring a license for Ecology Impact Analysis (AMDAL). Assessors and implementing certification for amdal document drafters and clarifying legal sanctions for violators in the field of analysis regarding environmental impact (Sloan and Ugandhy 1994). Environmental impact analysis is also one of the main requirements in obtaining an environmental permit, which is necessary before obtaining a business license. With the conditions related to an analysis of environmental impacts, controlling ecological damage can be minimized (Hernanda 2020).
Environmental crimes, by their very nature, are trans-boundary and involve cross-border criminal syndicates. In the era of global free trade, the ease of communication and movement of goods and money facilitates groups' operations involved in environmental crime. Preventive measures in controlling ecological impacts need to be carried out by making maximum use of monitoring and licensing instruments. If environmental pollution and damage have occurred, it is necessary to make repressive measures ineffective and consistent law enforcement against the air or water pollution and ecological damage that has occurred. In this regard, it is essential to develop a legal system for environmental protection and management that is clear, firm, and comprehensive to guarantee legal certainty as a basis for the protection and management of natural resources and other development activities. Law of the Republic of Indonesia Number 32/2009 concerning Environmental Protection and Management also uses various legal provisions, including administrative law, civil law, and criminal law. Civil law provisions include the settlement of environmental disputes outside the court and inside the court. The territory of ecological disputes in court includes class action suits, environmental organizations' lawsuit rights, or the government's right to sue. This method hoped that in addition to having a deterrent effect, it would also increase the awareness of all stakeholders about the importance of environmental protection and management for the lives of present and future generations. Besides, forest fires continue to occur in Indonesia every year; hence it is vital to reduce the problem of waste so that there is no increase in it every year.

Environmental crimes or crimes are contained in various laws and regulations other than the Republic of Indonesia Number 32/2009, concerned with Environmental Protection and Management and the Criminal Code. Therefore, law enforcers, especially investigators, public prosecutors, and judges, must find laws and regulations relating to environmental crimes (Kim 2009). Besides, Indonesia is also a country committed to realizing the 17 Goals and 169 targets of the SDGs global action plan from 2016 to 2030. Based on this description, the problems discussed in this paper are:

1. What are the efforts being made to enforce environmental law in Indonesia?

2. How is the relationship between environmental law enforcement and SDGs implementation in Indonesia?" 


\section{LITERATURE REVIEW}

\subsection{Research Accomplished}

Mark Elder and Simon Høiberg Olsen mentioned in their research that the environment was extensively incorporated into the Sustainable Development Goals (SDGs), with broad and ambitious targets, reflecting environmental concerns throughout the SDGs (Elder and Olsen 2019). Many environment-related targets including some of the most important ones - were placed under 'non-environmental' goals. The SDGs also adopted the view that economic growth can be made environmentally sustainable using 'decoupling' and 'resource efficiency' as critical technological solutions. In her research, Mary Menton et al. explained that through their synergies, trade-offs, and contradictions, the sustainable development goals (SDGs) could lead to environmental justice and injustices. Yet, environmental justice (EJ), and social justice more broadly, is not currently embedded within the language and spirit of the SDGs. Most recently, research from Jörn P. W. Scharlemann et al. mentioned that only ten years remain to achieve all Sustainable Development Goals (SDGs) globally, so there is a growing need to increase the effectiveness and efficiency of action by targeting multiple SDGs. Although some highlight the more environmentallyfocused SDGs' role in underpinning sustainable development, none focuses explicitly on the environment-human linkages (Scharlemann et al. 2020).

\subsection{Environmental Crimes}

There are a few environmental crime characteristics that make it worthwhile to devote a separate chapter to it. The field of environmental crime is different from traditional criminal law. In many legal systems, the central part of ecological criminal law cannot be found in penal codes containing the principal offenses. The central part of environmental criminal law consists of provisions incorporated in an administrative nature's environmental statutes and have, as their primary function, the enforcement of compliance with administrative obligations. Therefore, a great deal of environmental criminal law is not formulated independently but is instead developed as an accessory to regulation. An essential part of ecological criminal law will consist of violations of a regulatory nature in legal practice. For example, the polluter will be prosecuted for discharging certain substances into the environment without a permit or for violating permit conditions (Gibbs et al. 2010; Weinstein 2004).

\subsection{Sustainable Development Goals (SDGs)}

The 2030 Agenda for Sustainable Development or SDGs is a new development agreement that encourages changes to shift towards sustainable development based on human rights and equality to promote social, economic, and environmental development. SDGs are enforced with universal, integrated, and inclusive principles to ensure that no one will be overlooked or "No-one Left Behind." Leaving No One Left is the main principle of the SDGs. With these principles, at least the SDGs must answer two things (e.g., procedural justice and substantial justice). Procedural justice is the extent to which all parties, especially those left behind, can be involved in the whole development process. Substantial Justice is when developing policies and programs that can address citizens' problems, especially groups. On the other hand, the SDGs consist of 17 Goals and 169 targets to continue the Millennium Development Goals (MDGs,) which ended in 2015 (Griggs et al., 2013).

\subsection{Law of the Republic of Indonesia Number $32 / 2009$}

Criminal law enforcement in the Law of the Republic of Indonesia Number 32/2009 concerning Environmental Protection and Management introduces the threat of minimum and maximum penalties, expansion of evidence, punishment for violations of quality standards, integrated criminal law enforcement, and corporate crime regulation. Enforcement of environmental criminal law still observes the principle of ultimum remedium, which obliges the application of criminal law enforcement as a last resort after the implementation of administrative law enforcement is deemed unsuccessful. The ultimum remedium principle application only applies to certain formal crimes, namely punishment for violations of wastewater quality standards, emissions, and disturbances (Haris 2019)

\section{METHODOLOGY}

This normative research adopted a statutory and conceptual approach. Secondary data was obtained from library study and were further analyzed qualitatively.

\section{RESEARCH RESULT}

\subsection{Environmental Law Enforcement Efforts in Indonesia}

To protect and conserve the environment and maintain its sustainability, it is not enough to make 
rules regarding the prohibition of environmental destruction. Still, it is necessary to make law enforcement efforts. Law of the Republic of Indonesia Number 32/2009 concerning Environmental Protection and Management gives broad powers to the Minister to carry out all government authorities in environmental protection and management and coordinate with other agencies. Through the Law of the Republic of Indonesia Number 32 / 2009 concerning Environmental Protection and Management, the Government also gives extensive powers to local governments to protect and manage their respective regions' environment. Therefore, an institution that has a workload based on the Law of the Republic of Indonesia Number 32/2009 concerning environmental protection and management is not only an organization that determines and coordinates the implementation of policies. But including the organization with a portfolio of deciding, implementing procedures as well as supervising environmental protection and management policies. Besides, this institution is expected to have a scope of authority to oversee natural resources conservation purposes. To ensure the implementation of these institutions' main tasks and functions, funding support from the state revenue and expenditure budget is adequate for the Government and sufficient regional revenue and expenditure budgets for local governments. The objectiveness of the enactment law of Indonesia Number 32/2009, concerning Environmental Protection and Management, can be realized; if all people in the country must play a role in learning sustainable development. Second, to realize sustainable development within the framework of national development, economic, social, and ecological effects can be carried out. Third, federal law development in learning sustainable development needs to exist, and the legal action carried out must be comprehensive and interpreted broadly.

Crime is an obstacle to the progress of a nation. Corporations carry out many of the problems of environmental crimes in Indonesia, and usually, the damage they cause is ecological damage and pollution on a large scale. Indonesia is a country where environmental problems are very concerning. Many cases of environmental pollution and illegal logging have caused devastating impacts on the environment. The provisions of criminal law in Law of the Republic of Indonesia Number 32/2009 concerning Environmental Protection and Management are regulated from Article 97 to Article 120. The requirements of the Republic of Indonesia Number 32 /2009 concerning Environmental
Protection and Management; stipulate that a person was giving orders to commit environmental crime or person was acting as a leader in an ecological crime committed (by, for, or on) behalf of a business entity, the penalty of imprisonment and a fine up to one third. Currently, the enforcement of criminal law in the environmental sector has not achieved the expected goals. One of the causes of this failure is the lack of synchronization, coordination, and harmony culturally, structurally, and substantially in the criminal justice system-including preventive and repressive action for realized SDGs. The meaning of preventive is the same as compliance, including negotiation, supervision, information, and advice, while repressive means to investigate to apply both administrative and criminal sanctions (Dewi 2012). Thus, environmental law enforcement is a law enforcement process that is optional so that law enforcers can choose which approach is the best to enforce.

Environmental law enforcement in the Law of the Republic of Indonesia Number 32 of 2009 is preventive and repressive. Preventive measures in the context of controlling ecological impacts need to be carried out by making maximum use of monitoring and licensing instruments, which can be carried out by the government, regional government, and the community. Repressive measures are carried out if environmental pollution and damage have occurred, either through administrative law instruments, civil law instruments, or criminal law instruments. Siregar and Zul (2015) state the ecological crime committed (for; or; on) behalf of a legal entity, at least therein, that:

1. The illegal acts of legal entities and their agents differ from the lower socio-economic class's criminal behavior regarding administrative procedures. Therefore, what a legal entity does is a crime against criminal law and a violation of civil and administrative law.

2. Both legal entities (as "legal persons") and their representatives are included as criminals (as illegal actors), which in their judicial practice, among others, depends on the crimes committed, the rules, and the quality of evidence and prosecution.

3. The motivation for crimes committed by legal entities is aimed at personal gain and meeting needs and achieving organizational gain. These motives may also be supported by operational (internal) norms and organizational sub-culture. 
Using the precautionary principle in granting permits for companies and individuals is the next important aspect because licensing is given as legalization (juridical aspect) to monitor ongoing environmental management or utilization activities (Machmud 2019). Enforcement of environmental laws deals with various quite complex elements to maintain and create an environment that can be enjoyed by every human being in a broad sense without disturbing the environment itself. Multiple forms of statutory regulations have been made in laws and various implementing regulations in capturing irresponsible parties' attitudes. In environmental law enforcement, it can be said that environmental law is a rule of law that can apply and function in society as described above. According to the Indonesian language, especially environmental law enforcement, law enforcement is meant that enforcement is repressive and prevents environmental violations from occurring. So that in this case, it involves all law enforcement officers, including increasing public awareness, which includes extension activities, information dissemination, education, both formal and non-formal. Legal laws regarding the environment are also expected to support environmental law principles (Sodikin, 2010). Without this, environmental law enforcement will undoubtedly experience several obstacles, so that if it is allowed to continue, it will result in more severe environmental damage.

In the SDGs era, the state is interested in realizing a sustainable life even though it has to compete in controlling pollution and environmental damage (Żmuda 2020). Preventive measures in preventing ecological impacts need to be carried out by making maximum use of monitoring and licensing instruments. If environmental pollution and damage have occurred, it is necessary to make repressive measures consistently ineffective and consistent law enforcement against the pollution and ecological damage that has occurred. Therefore, there is a need to develop a legal system for environmental protection and management that is clear, firm, and comprehensive to guarantee legal certainty as a basis for protecting and managing natural resources and other development activities. Thus, it can be said that the enforcement of environmental laws is very complicated because environmental law is a field of law with many aspects. Enforcement of environmental law through preventive and repressive measures also varies, from legal counseling to the application of penalties in the form of sanctions, both administrative and criminal sanctions, including civil compensation.
Meanwhile, through legal counseling utilizing being promoted (socialized) from the mass media to lectures and discussions and how to overcome it, it must also be started from oneself to society as a whole. Therefore, the framework of environmental law enforcement in Indonesia includes preventive and repressive compliance and enforcement covering administrative law, civil law, and criminal law. Thus, within the framework of environmental law enforcement in Indonesia, preventive and repressive compliance and enforcement covering administrative law, civil law, and criminal law are included. Repressive actions using legal instruments in environmental law enforcement (e.g., administrative, civil, and criminal law) are currently believed to be the most effective; even the three instruments can be applied at once. Following the Indonesian Law Number 32/2009 concerning Environmental Protection and Management, there are three legal instruments in environmental law enforcement: administrative law, civil law, and criminal law (Sodikin 2010). The regulations are also enforced by different law enforcers if the administrative official's administrative, legal instrument. In this case, the government is authorized to do so, civil law instruments by the injured party, either individually or as a legal entity, criminal law instruments by the police then forwarded by the prosecutor. Every standard tool has its scope with objectives on a proportional scale depending on the interests to be resolved.

\subsection{Relationship between Environmental Law Enforcement and SDGs Implementation in Indonesia}

Criminal law enforcement is an essential aspect of law enforcement against environmental destroyers. Even in Poland and Russia, environmental protection through criminal law has a significant impact (Solodov and Zębek 2020). It is not much different from what is done by the parliament in the United States, which pays great attention to criminal sanctions to achieve environmental goals (DiMento 1993). In the Indonesian context, the Law of the Republic of Indonesia Number $32 / 2009$, which are based on good governance because in every process, the formulation and application of preventive instruments environmental pollution and damage, as well as the prevention and enforcement of the law, requires the integration of aspects of transparency, participation, accountability, and justice. The provisions in the Law of the Republic of Indonesia Number 32/2009 concerning Environmental Protection and Management (Listiyani and Said 2018): 
1. the integrity of the elements of environmental management;

2. clarity of authority between central and local governments;

3. strengthening efforts to control the environment;

4. strengthening of instruments for preventing pollution or ecological damage, including mechanisms for strategic environmental studies, spatial planning, environmental quality standards, standard criteria for environmental damage, analysis of environmental impacts, environmental management efforts, and environmental monitoring efforts, licensing, environmental, economic instruments, environmental-based laws and regulations, environmental-based budgets, ecological risk analysis, and other agencies under the development of science and technology;

5. utilization of licensing as an instrument of control;

6. utilization of an ecosystem approach;

7. certainty in responding to and anticipating developments in the global environment;

8. strengthening of environmental democracy through access to information, access to participation, and access to justice as well as strengthening community rights in environmental protection and management;

9. more transparent civil, administrative and criminal law enforcement;

10. strengthening of institutions for environmental protection and control that are more effective and responsive; and

11. strengthening the authorities of environmental supervisors and investigators of environmental civil servants.

The state has become an important actor in global action. Right now, the world is not on track to meet environmental targets. We can still achieve the SDGs, but to do so, we've got to ramp up efforts to cut down on pollution, use resources efficiently, and better protect the environment (Zeng et al. 2020). The Goals at points $6,7,12,13,14$, and 15 on SDGs are directly related to SDGs' environmental sustainability (Arora and Mishra 2019). These goals' targets are mainly linked to the natural environment but lag and seem impossible to achieve in the due time frame. Every human being must be able to protect and manage the ground to remain sustainable. Therefore, in enforcing environmental law, the Law of the Republic of Indonesia Number 32/2009 concerning Environmental Protection and Management places law enforcement not only through the three legal instruments as described above.

However, law enforcement in a preventive sense, namely by socializing Law of the Republic of Indonesia Number 32/2009. These preventive measures in controlling environmental impacts need to be carried out by making maximum use of monitoring and licensing instruments. The supervisory and licensing agency, in this case, is the government, both central and regional governments. The government is expected to apply the principles of environmental protection and management based on good governance. In every process, the formulation and implementation of instruments for preventing environmental pollution and destruction and their prevention require integrating aspects of transparency, participation, accountability, and justice. Of course, this is to create a clean and authoritative government and transparent to realize the social justice coveted together. As a form of environmental law enforcement, the Law of the Republic of Indonesia Number 32/2009 gives broad powers to the relevant Ministers as government officials to carry out all government authorities in environmental protection and management. Through this Law, the government also offers extensive capabilities to local governments to protect and manage the environment in their respective regions so that the environment remains sustainable. This is in line with the Goals in points $6,7,12,13,14$, and 15 of the SDGs.

The physical, natural, applied, and social sciences and the humanities all have a role in finding long-term solutions for the SDGs (Lu et al., 2015). As the protection and environmental management, it is necessary to strengthen law instruments for the prevention of pollution and ecological destruction. Including strategic for environmental studies, spatial planning, environmental quality standards, standard criteria for environmental damage, analysis of environmental impacts, environmental management efforts, and environmental monitoring efforts, licensing, environmental, economic instruments, environmentbased laws and regulations, environmental-based 
budgets, ecological risk analysis, and other devices by the development of science and technology. Besides, the Law of the Republic of Indonesia Number 32/2009 also regulates the rights, obligations, and participation of the community in protecting and managing the environment to preserve environmental functions and control over the wise use of resources. Legal protection of human rights is one of the most effective means of protecting the environment. Human rights and the environment are dependent on one another. Regulations regarding the protection of the environment can simultaneously preserve human rights, especially those related to issues of the right to life, the right to health, the right to business, the right to development, freedom from interference with property rights, to the granting of protection rights for rural communities. David Hunter stated that human rights are a model for the progressive development of international environmental law and a potential independent tool for protecting the environment (Hunter, Salzman, and Zaelke 1998). This shows that understanding and recognizing human rights means preserving the domain used to achieve sustainable development. This is because recognizing and protecting human rights is a possible way to protect the environment (Magers 2020).

SDGs Agenda ensures that all human beings can fulfill their potential in dignity and equality, and a healthy environment. In the rapidly changing world, it takes political will from the state to strive to create a sustainable environment (Magers 2020). The availability of natural resources in quantity or quality is not evenly distributed, while development activities require increasing natural resources. Development activities also carry the risk of pollution and environmental damage. This condition can cause the carrying capacity and ecological productivity to decrease, which becomes a social burden. Therefore, Indonesia's environment must be adequately protected and managed based on state responsibility principles, sustainability principles, and justice principles. Besides, environmental management must provide economic, social, and cultural benefits based on the principles of prudence, environmental democracy, decentralization, and recognition and respect for local and ecological wisdom. Environmental protection and management require developing an integrated system in the form of a national policy on environmental protection and control, which must be implemented according to principles and consequences from the center to the regions. Thus, Indonesia's effort to enforce Goals of 6 ,
$7,12,13,14$, and 15 is directly related to environmental sustainability.

\section{CONCLUSIONS}

The enforcement of environmental law in Indonesia is regulated in the Republic of Indonesia Number 32 the Year 2009 concerning Environmental Protection and Management in a preventive and repressive nature. The law also recognizes three legal instruments in environmental law enforcement, namely administrative law, civil law, and criminal law. Environmental law enforcement and the implementation of SDGs in Indonesia are connected with preventive and repressive enforcement as regulated in Law of the Republic of Indonesia Number $32 / 2009$ by granting extensive powers to local governments to provide protection and environmental management in their respective regions so that the environment remains sustainable. The law in line with the Goals at $6,7,12,13,14$, and 15 of the SDGs are directly related to environmental sustainability.

\section{ACKNOWLEDGEMENT}

Thanks to Universitas Kristen Paulus, Makassar and Dr. Kadarudin from Universitas Hasanuddin for useful comments and support.

\section{REFERENCE}

Albrizio, Silvia, Tomasz Kozluk, and Vera Zipperer. 2017. "Environmental Policies and Productivity Growth: Evidence across Industries and Firms." Journal of Environmental Economics and Management. https://doi.org/10.1016/j.jeem.2016.06.002

Arora, Naveen Kumar, and Isha Mishra. 2019. "United Nations Sustainable Development Goals 2030 and Environmental Sustainability: Race against Time." Springer. https://doi.org/10.1007/s42398-019-00092-y

Bhuian, Shahid, and Sujeet Kumar Sharma. 2017. "Predicting Consumer Pro-Environmental Behavioral Intention: The Moderating Role of Religiosity." Review of International Business and Strategy 27 (3): 352-68. https://doi.org/10.1108/RIBS-03-2017-0022

Dewi, Dyah Adriantini Sintha. 2012. "Konsep Pengelolaan Lingkungan Hidup Menuju Kemakmuran Masyarakat." Jurnal Fakultas Hukum Universitas Muhammadiyah Magelang 1 (1): 23268.

DiMento, Joseph F. 1993. "Criminal Enforcement of Environmental Law." The Annals of the American Academy of Political and Social Science 525 (1): 134-46. https://doi.org/10.1177/0002716293525001011

Elder, Mark, and Simon Høiberg Olsen. 2019. "The Design of Environmental Priorities in the SDGs." Global Policy 10 (S1): 70-82. https://doi.org/10.1111/1758-5899.12596

Gibbs, Carole, Meredith L Gore, Edmund F McGarrell, and Louie Rivers III. 2010. "Introducing Conservation Criminology: Towards Interdisciplinary Scholarship on Environmental 
Crimes and Risks." The British Journal of Criminology 50 (1): 124-44.

https://doi.org/10.1093/bjc/azp045

Griggs, David, Mark Stafford-Smith, Owen Gaffney, Johan Rockström, Marcus C Öhman, Priya Shyamsundar, Will Steffen, Gisbert Glaser, Norichika Kanie, and lan Noble. 2013. "Sustainable Development Goals for People and Planet." Nature 495 (7441): 305-7. https://doi.org/10.1038/495305a

Haris, Oheo K. 2019. "Legal Environmental Action Aspects, Based on Environmental Conservation, According to Law 32/2009 Concerning Protection and Management of Environment." In 2nd International Conference on Indonesian Legal Studies (ICILS 2019), 453-59. Atlantis Press.

Hernanda, Trias. 2020. "Legal analysis on amdal as an environmental protection document." Legal Standing: Jurnal IImu Hukum 4 (2): 108-15. https://doi.org/10.24269/ls.v4i2.2980

Hidjaz, Kamal. 2019. "Effectiveness of Environmental Policy Enforcement and The Impact by Industrial Mining, Energy, Mineral, And Gas Activities In Indonesia." International Journal of Energy Economics and Policy 9 (6): 79-85. https://doi.org/10.32479/ijeep.8146

Hooper, David U, F S Chapin lii, J J Ewel, Andrew Hector, Pablo Inchausti, Sandra Lavorel, John Hartley Lawton, D M Lodge, Michel Loreau, and Shahid Naeem. 2005. "Effects of Biodiversity on Ecosystem Functioning: A Consensus of Current Knowledge." Ecological Monographs 75 (1): 3-35. https://doi.org/10.1890/04-0922

Hunter, David, J Salzman, and D Zaelke. 1998. International Environmental Law.

Kim, So Woong. 2009. "Kebijakan Hukum Pidana Dalam Upaya Penegakan Hukum Lingkungan Hidup." Program Pasca Sarjana Universitas Diponegoro.

Listiyani, Nurul, and M Yasir Said. 2018. "Political Law on the Environment: The Authority of the Government and Local Government to File Litigation in Law Number 32 Year 2009 on Environmental Protection and Management." Resources 7 (4): 77. https://doi.org/10.3390/resources 7040077

Lu, Yonglong, Nebojsa Nakicenovic, Martin Visbeck, and AnneSophie Stevance. 2015. "Policy: Five Priorities for the UN Sustainable Development Goals." Nature 520 (7548): 43233. https://doi.org/10.1038/520432a

Machmud, Syahrul. 2019. "Tindakan Preventif Dan Represif NonYustisial Penegakan Hukum Administrasi Oleh Eksekutif." Jurnal Hukum Media Justitia Nusantara 7 (2): 62-77.

Magers, Jens. 2020. "Sustainable Investment Law-How to Legally Implement Sustainable Standards." In The Future of the UN Sustainable Development Goals, 309-37. Springer. https://doi.org/10.1007/978-3-030-21154-7 16

Murdifin, Imaduddin, Muhammad AR Faisal Pelu, Aditya Halim Perdana Kusuma Putra, A Muara Arumbarkah, Aulia Rahmah, Universitas Muslim Indonesia, Manunggal Halim Jaya, et al. 2019. "Environmental Disclosure as Corporate Social Responsibility: Evidence from the Biggest Nickel Mining in Indonesia." International Journal of Energy Economics and Policy 9 (1). https://doi.org/10.32479/ijeep.7048
Nazir, Munawir, Imaduddin Murdifin, Aditya Halim Perdana Kusuma Putra, Nasir Hamzah, and Moch Zulkifli Murfat. 2020. "Analysis of Economic Development Based on Environment Resources in the Mining Sector." The Journal of Asian Finance, Economics and Business (JAFEB) 7 (6): 133-43. https://doi.org/10.13106/jafeb.2020.vol7.no6.133

Obidzinski, Krystof, Rubeta Andriani, Heru Komarudin, and Agus Andrianto. 2012. "Environmental and Social Impacts of Oil Palm Plantations and Their Implications for Biofuel Production in Indonesia." Ecology and Society 17 (1). https://doi.org/10.5751/ES-04775-170125

Saputro, Bangun Tri, and Basuki. 2019. "Carbon Emission Disclosure in Manufacturing Companies in Indonesia." Indian Journal of Public Health Research and Development. https://doi.org/10.5958/0976-5506.2019.02647.0

Scharlemann, Jörn P W, Rebecca C Brock, Nicholas Balfour, Claire Brown, Neil D Burgess, Miriam K Guth, Daniel J Ingram, et al. 2020. "Towards Understanding Interactions between Sustainable Development Goals: The Role of EnvironmentHuman Linkages." Sustainability Science. https://doi.org/10.1007/s11625-020-00799-6

Siregar, Januari, and Muaz Zul. 2015. "Penegakan Hukum Dalam Tindak Pidana Lingkungan Hidup Di Indonesia." Jurnal Mercatoria 8 (2): 107-31.

Sloan, N A, and A S Ugandhy. 1994. "An Overview of Indonesian Coastal Environmental Management." https://doi.org/10.1080/08920759409362233

Sodikin, Sodikin. 2010. "Penegakan Hukum Lingkungan Menurut Undang-Undang Nomor 32 Tahun 2009 Tentang Perlindungan Dan Pengelolaan Lingkungan." Kanun Jurnal IImu Hukum 12 (3): 543-63.

Solodov, Denis, and Elżbieta Zębek. 2020. "Environmental Criminal Enforcement in Poland and Russia: Meeting Current Challenges." Utrecht Law Review 16 (1) https://doi.org/10.36633/ulr.532

Suriyanti, Suriyanti, Ahmad Firman, Nurlina Nurlina, Gunawan Bata llyas, and Aditya Halim Perdana Kusuma Putra. 2020. "Planning Strategy of Operation Business and Maintenance by Analytical Hierarchy Process and Strength, Weakness, Opportunity, and Threat Integration for Energy Sustainability." International Journal of Energy Economics and Policy 10 (4): 221-28. https://doi.org/10.32479/ijeep.9267

Weinstein, Tara. 2004. "Prosecuting Attacks That Destroy the Environment: Environmental Crimes or Humanitarian Atrocities." Geo. Int'l Envtl. L. Rev. 17: 697.

White, Rob. 2014. "Environmental Regulation and Law Enforcement BT - Encyclopedia of Criminology and Criminal Justice." In , edited by Gerben Bruinsma and David Weisburd, 1355-67. New York, NY: Springer New York. https://doi.org/10.1007/978-1-4614-5690-2_284

Zeng, Yiwen, Sean Maxwell, Rebecca K Runting, Oscar Venter, James E M Watson, and L Roman Carrasco. 2020. "Environmental Destruction Not Avoided with the Sustainable Development Goals." Nature Sustainability, 1-4. https://doi.org/10.1038/s41893-020-0555-0

Żmuda, Małgorzata. 2020. "National Competitiveness and Sustainability: Friends or Foes." In The Future of the UN Sustainable Development Goals, 291-307. Springer https://doi.org/10.1007/978-3-030-21154-7 15

\section{DOI: https://doi.org/10.6000/1929-4409.2021.10.60}

(C) 2021 Salim and Palullungan; Licensee Lifescience Global.

This is an open access article licensed under the terms of the Creative Commons Attribution Non-Commercial License (http://creativecommons.org/licenses/by-nc/3.0/) which permits unrestricted, non-commercial use, distribution and reproduction in any medium, provided the work is properly cited. 